\title{
Desa-Desa Kuna Pantai Selatan Jawa
}

\section{Goenadi Nitihaminoto}

Keywords: ancient villages, java, coastal, settlement, protohistory, community, subsistence

\section{How to Cite:}

Nitihaminoto, G. (2004). Desa-Desa Kuna Pantai Selatan Jawa. Berkala Arkeologi, 24(1), 14-28. https:// doi.org/10.30883/jba.v24i1.890

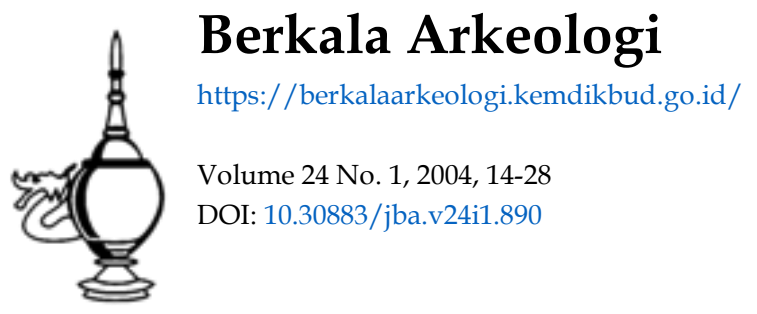

\section{(c) (i) (2)}

This work is licensed under a Creative Commons Attribution-NonCommercial-ShareAlike 4.0 International License. 


\title{
DESA-DESA KUNA PANTAI SELATAN JAWA
}

\author{
Goenadi Nh
}

\section{$\mathbf{P}$} endahuluan

Desa merupakan organisasi administrasi pemerintahan paling kecil terdiri atas beberapa kampung atau dusun. Wilayah suatu desa memiliki batas-batas jelas yang pada umumnya berupa sungai, jalan, atau berbatasan dengan desa lain di sebelahnya. Warga desa terdiri atas beberapa puluh orang, bahkan hingga ribuan orang jumlahnya yang menghuni suatu tempat. Desa memiliki aturan-aturan yang mengikat bagi warganya yang dipimpin oleh seorang kepala desa. Kepala desa mempunyai tugas untuk mengatur para warganya dalam berbagai bidang agar dicapai suatu kesejahteraan warganya. Aktivitas kehidupan sehari-hari cenderung bersifat homogen dan keadaan itu berbeda dengan struktur organisasi pemerintahan kota yang bersifat heterogen.

Uraian sekilas di atas, tampaknya mirip dengan struktur administrai pemerintahan suatu negara dengan demikian desa diibaratkan sebagai negara dalam bentuk kecil.Istilah desa seperti uraian tersebut merupakan gambaran desa yang dapat kita lihat sekarang, tetapi keadaan pada masa lampau tidak banyak diketahui. Meskipun demikian kata desa itu dapat diduga munculnya sejak Kerajaan Mataram Islam berkembang mulai abad ke-17, karena pada masa Majapahit tidak ditemukan kata desa, melainkan thani yang artinya sama dengan desa. Demikian pula pada masa-masa sebelumnya, yaitu antara abad ke-7 hingga abad ke-13 tidak ditemukan kata desa, tetapi pada kurun waktu yang panjang itu tampaknya wanua dapat disamakan dengan pengertian desa. Lebih jauh lagi, terutama sejak awal Masehi hingga abad ke-6 tidak diketahui kata desa atau padanannya.

Dari uraian itu, desa kuna yang dimaksud dalam tulisan ini adalah desa-desa yang terdapat di pantai selatan Jawa yang berasal dari awal Masehi hingga abad ke-17. Desa-desa kuna di pantai selatan Jawa telah diteliti, sehingga sisa-sisa kehidupannya dapat dijadikan petunjuk adanya suatu komunitas atau suatu masyarakat yang pernah beraktivitas di wilayah pantai itu. Komunitas yang beraktivitas di suatu desa tidak dapat dipisahkan dengan komunitas di desa lain dan bahkan terjalin hubungan langsung atau tidak langsung dengan komunitas kota yang terletak paling dekat dengan desa itu. Berdasarkan keletakannya itu apabila dibandingkan dengan desa lain atau kota yang berada di sebelah utaranya, maka desa-desa kuna di tepi pantai itu termasuk desa-desa pinggiran atau desa-desa marginal. Berdasarkan keletakannya itu pula, desa-desa itu memiliki tingkat homogenitas tinggi dalam cara-cara hidup mereka, seperti matapencaharian dan kepercayaan mereka, terutama desa-desa yang paling tua. Desa-desa yang berasal dari awal Masehi hingga abad ke-6 tentu memiliki 
ciri lain dibanding dengan desa-desa yang lebih muda dari pertanggalan itu, misalnya batas-batas wilayah desa dan jumlah penduduk tidak sejelas sekarang.

Berdasarkan bukti-bukti berupa sisa-sisa kehidupan yang pernah diteliti, desa-desa itu tersebar di pantai selatan Jawa Timur, D.I. Yogyakarta, dan Jawa Tengah. Desa-desa kuna di pantai selatan Jawa Barat, sampai saat ini belum ditemukan, meskipun beberapa wilayah pantai selatannya telah diteliti. Penelitian di wilayah pantai selatan Sukabumi, pantai timur Rangkasbitung, dan pantai barat Cianjur tidak ditemukan sisasisa kehidupan desa kuna, lebih-lebih pantai selatan Garut, Tasikmalaya, dan Ciamis belum pernah diteliti. Penelian permukiman pantai di sebelah timurnya hingga ke pantai selatan Jawa Timur, khususnya dari Cilacap hingga Pacitan, hasilnya telah disampaikan oleh van der Hoop (1938: 95; 1945: 21), berupa pecahan tembikar berpola hias. Pecahan tembikar tersebut dapat dianggap sebagai sisa kehidupan dari suatu komunitas yang menghuni desa-desa kuna di wilayah pantai tersebut. Kekurangan van der Hoop, tidak menyebut lokasi tempat tembikar kuna ditemukan. Berangkat dari informasi itu, Balai Arkeologi Yogyakarta tertarik untuk mengembangkan penelitian sisa-sisa permukiman pantai yang dilakukan mulai tahun 1980 dan diteruskan pada tahun-tahun berikutnya, hingga ke wilayah Jawa Timur bagian timur.

Desa kuna di wilayah Jawa Tengah ditemukan di bagian barat, tepatnya di wilayah kabupaten Kebumen terletak di Situs Ayamputih, kemudian makin ke timur terdapat beberapa desa kuna lainnya yang masing-masing terletak di pantai selatan wilayah kabupaten Purworejo, Bantul, Gunung Kidul, Trenggalek, Lumajang, dan Jember. Desa-desa tersebut terletak di situs-situs Ayamputih (Kebumen), Wingkosigromulyo (Purworejo), Gunungwingko (Bantul), Krakal (Gunung Kidul), Panggul (Trenggalek), Meleman dan Tempursari (Lumajang), Jatiagung dan Panggulmlati (Jember). Untuk memudahkan penyebutannya, desa-desa kuna yang terdapat di situs-situs itu disesuaikan dengan nama situs, desa kuna yang terdapat di dekat situs, atau desa terdekat di dekat lokasi situs. Dengan demikian, desa-desa kuna itu disebut Desa Setrojenar di Situs Ayamputih, Desa Wingko di Situs Wingkosigromulyo, Desa Gunungwingko di Situs Gunungwingko, Desa Krakal di Situs Krakal, Desa Panggul di Situs Panggul, Desa Meleman di Situs Meleman, Desa Karangmenjangan di Situs Tempursari, Desa Jatiagung di Situs Gumukmas, dan Desa Panggulmlati di Situs Gumukmas.

Jumlah temuan, keanekaragamannya, dan luas situs dijadikan ukuran untuk menentukan suatu desa berukuran besar, sedang, dan kecil. Berdasarkan akumulasi temuan dan keanekaragaman itu, maka desa yang paling besar adalah Desa Gunungwingko, sedangkan desa-desa lainnya berukuran sedang. Bahkan, dalam survei tahun 1980 diketahui adanya desa-desa yang lebih kecil. Desa-desa kecil itu tersebar di seluruh pantai selatan dan berada di antara desa-desa yang berukuran 
sedang. Desa-desa kecil itu antara lain ditandai oleh pecahan tembikar kuna, yaitu Tambak (Kebumen), Jangkaran (Purworejo), Glagah (Kulon Progo), Trisik dan Bibis (Bantul), Wedi Ombo dan Denombo (Gunung Kidul), dan Bakung (Pacitan). Selain ukuran luas desa berbeda, pertanggalannya pun berbeda. Pertanggalan yang digunakan untuk menentukan suatu desa kuna didasarkan pada hasil analisis pertanggalan $\mathrm{C}_{14}$ dan pertanggalan relatif. Media pertanggalan absolut berasal dari tulang manusia dan arang, sedangkan pertanggalan relatif dihasilkan dari perbandingan temuan dengan temuan sejenis yang telah diketahui pertanggalan absolutnya. Selain itu, pertanggalan relatif didasarkan pula pada peristiwa alam besar seperti letusan gunungapi. Pembentukan lahan yang dipengaruhi oleh erupsi gunungapi menjadi salah satu pertimbangan dalam memilih lokasi permukiman, selain pertimbangan-pertimbangan lainnya.

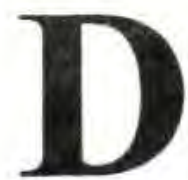

\section{esa-desa Kuna}

Pemilihan lokasi permukiman merupakan hasil pertimbangan sebelum suatu lomunitas bermukim di suatu bentuklahan. Pertimbangan-pertimbangan itu berlatarbelakang ekonomi agar kehidupan yang ditempuh dapat berlangsung lancar dan menjanjikan. Pertimbangan seperti itu tidak dilakukan untuk permukiman masa kini, tetapi permukiman masa lampau diyakini menggunakan pertimbangan yang sama. Kesuburan tanah, sumber air, keadaan fauna dan flora merupakan aspek-aspek lingkungan alam yang dijadikan pertimbangan utama agar dapat dieksploitasi secara maksimal, demi kelangsungan hidup mereka. Lingkungan alam wilayah pantai berbeda dengan bentuklahan-bentuklahan lain, dataran, lahan di lereng gunung, dan bentuklahan lain. Masing-masing bentuklahan memiliki spesifikasi unsur lingkungan alam yang berbeda. Bentuklahan di wilayah pantai, pada umumnya merupakan dataran aluvial. Dataran aluvial dicirikan oleh adanya beberapa aspek lingkungan alam, seperti sumber air, gisik, beting gisik, fauna, dan flora.

Sumberdaya akuatik wilayah pantai berasal dari air laut, sungai, rawa, dan air tanah yang berasal dari beting gisik, terutama beting gisik tua. Sumberdaya akuatik tersebut mengandung flora dan fauna yang dapat dieksploitasi untuk kelangsungan hidup manusia, karena memberi protein hewani dan nabati. Gisik dan beting gisik merupakan bentuklahan yang terjadi sebagai akibat kegiatan proses marin yang berasal dari aktivitas gelombang. Sebagian bentuklahan, dihasilkan oleh tenaga gabungan antara proses marin dan proses angin yang terjadi pada satuan bentuklahan yang terletak jauh dari garis pantai (Mundardjito, 1993: 110-112; Sutikno et al: 1989: 22). Proses endapan oleh angin menimbulkan terbentuknya endapan aeolian atau sand dune. Terbentuknya beting gisik dan endapan aeolian tersebut mengakibatkan daratan bertambah luas menuju ke arah laut yang biasa terjadi di pantai selatan Jawa (Pannekoek, 1949: 270). 
Daratan bertambah luas ke arah laut disebabkan oleh krisis lingkungan terutama terjadi proses deposisi lahan yang berhubungan dengan aktivitas gunungapi. Proses perkembangan bentuklahan yang menjadi penyebab antara lain pembentukan beting gisik (beach ridge), pembentukan endapan aeolian--khususnya gumuk pasir (sand dune)--, dan pembentukan-pembentukan lahan lain, misalnya cekungan antarbeting gisik (swale). Gelombang dan arus susur pantai membawa material yang dibawa oleh arus air sungai yang bermuara di pantai selatan. Material yang dibawa oleh arus sungai terendapkan di tepi pantai, kemudian dibawa oleh gelombang dan arus susur pantai, lama kelamaan membentuk gisik. Material itu sebagian besar berupa pasir berbutir sedang hingga halus, karena dibawa jauh dari sumbernya. Endapan yang terjadi secara terus menerus sepanjang tahun, lama kelamaan membentuk punggungan pantai yang dikenal sebagai beting gisik (Dibyosaputro, 1997: 76).

Sementara itu, di belakang beting gisik yang telah terbentuk terdapat genangan air, karena terbendung oleh endapan beting gisik tersebut. Air yang menggenang itu berasal dari air laut yang bercampur dengan air hujan. Ketika air kering, karena terjadi pendangkalan akibat akumulasi pasir yang tertiup angin ke tempat itu dan penguapan air yang disebabkan oleh sinar matahari, setelah beberapa waktu berubah menjadi daratan dengan bentuk permukaannya cekung yang dikenal sebagai cekungan antarbeting gisik (swale). Proses pembentukan beting gisik berjalan terus selama material pembentuknya tersedia, sehingga terjadi pembentukan beting gisik kedua atau beting gisik ketiga. Pembentukan beting gisik itu diikuti pembentukan gumuk pasir yang mengendap di atas beting gisik. Proses pembentukan gumuk pasir berlangsung bertahap, tergantung pada keadaan musim dan angin yang membawa pasir-pasir berbutir halus. Pengendapan pasir oleh angin yang berlangsung secara bertahap itu menyebabkan endapan aeolian terdiri atas beberapa lapisan endapan dan ketinggian puncaknya berbeda-beda, karena tergantung pada tumbuhan yang berfungsi sebagai alat penjebak. Akibatnya beting gisik yang ada tumbuhannya akan terendapi oleh endapan aeolian lebih tebal daripada permukaan yang tidak ada tumbuhannya. Makin banyak tumbuhan yang menghalanginya, makin tinggi puncak gumuk pasir itu (Reineck dan Singh, 1975: 196-7). Perkembangan daratan ke arah laut yang berlangsung terus menerus dan adanya susut laut menyebabkan letak situs arkeologi makin jauh dari garis pantai yang ada sekarang.

Berdasarkan lingkungan alam itu, maka desa-desa kuna di wilayah pantai, bekasbekasnya terletak pada beting gisik tua yang di atasnya terdapat endapan aeolian (bukit pasir), terletak antara 500 meter hingga 8 kilometer di sebelah utara garis pantai, dan terletak di dekat sungai sampai 2 kilometer atau lebih. Selain keletakan itu, ciri-ciri lain keberadaan desa kuna tersebut adalah pecahan tembikar, tulang manusia, artefak yang dibuat dari logam, tulang, dan batu, dan sisa-sisa makanan berupa tulang beberapa jenis hewan. Semua jenis temuan itu tidak terdapat di semua situs, tetapi kandungan setiap situs berbeda. Sebagian situs mengandung pecahan tembikar, 
sebagian lagi mengandung pecahan tembikar dan tulang hewan, situs lain mengandung pecahan tembikar, artefak, tulang manusia, dan tulang hewan. Tulang manusia, baik yang membentuk struktur kubur maupun berupa pecahan terdapat di beberapa situs. Temuan yang beraneka ragam jenisnya yang jumlah keseluruhannya sangat banyak dan terdapat pada situs yang cukup luas, menggambarkan bekas desa besar, sedangkan situs-situs lain yang memiliki karakter lebih sederhana diidentifikasi sebagai desa yang lebih kecil. Desa-desa kuna di pantai selatan Jawa diuraikan sebagai berikut.

\section{Desa Setrojenar}

Bekas desa kuna ini terletak antara 250 meter hingga 500 meter di sebelah utara pantai Samudera Hindia. Luasnya sekitar 30 hektar dengan panjang 3000 meter dan lebarnya 100 meter. Kali Luk Ulo meupakan batas desa di bagian barat, berjarak sekitar dua kilometer. Artefak yang pernah digunakan terletak di bukit pasir yang keletakannya tidak merata. Keletakan artefak itu berkelompok di bebepara bagian bukit pasir yang memanjang sepanjang lebih kurang 3000 meter. Artefak yang ditemukan berupa pecahan tembikar yang berasal dari periuk yang pada bagian badannya diberi pola hias dengan motif duri ikan. Motif hias itu dihasilkan dari tatap berukir (paddle carved) yang diterakan pada waktu proses pembentukan berlangsung.

Temuan yang tidak merata dan artefak yang berasal dari jenis sama menggambarkan adanya aktivitas khusus, bukan aktivitas kehidupan sehari-hari. Selain itu, jumlah temuannya tidak banyak. Berdasarkan kenyataan itu, aktivitas di atas bukit pasir di desa tersebut diduga sebagai aktivitas ritual. Dengan demikian, aktivitas itu berasal dari penduduk desa masa lampau yang bertempat tinggal di Desa Setrojenar yang terletak di sebelah timurnya atau desa-desa yang terletak di sebelah utara tempat aktivitas itu.

\section{Desa Wingko}

Lokasi desa itu sekarang terletak antara tujuh kilometer hingga delapan kilometer di sebelah utara pantai Samudera Hindia. Keletakan yang cukup jauh dari pantai membuktikan bahwa di wilayah ini pernah terjadi deposisi lateral yang cukup besar, sehingga menyebabkan desa tersebut terletak lebih jauh dari pantai yang ada sekarang. Luas desa tidak diketahui dengan tepat, tetapi daerah yang diteliti berukuran panjang 180 meter dan lebarnya sekitar 80 meter. Pada awalnya desa tersebut lebih luas daripada keadaannya sekarang. Pembangunan rumah-rumah penduduk yang telah memadati situs tersebut, menyebabkan ruang penelitian menjadi lebih sempit. Secara toponemis, Desa Wingko merupakan desa besar, karena wingko berarti pecahan tembikar. Desa-desa yang mengandung arti pecahan tembikar itu adalah Wingkosigromulyo, Wingkotinumpuk, dan Wingkosanggrahan. 
Artefak yang ditemukan sebagai salah satu bukti aktivitas yang pernah dilakukan adalah pecahan tembikar. Bentuk dan motif hias tembikar yang pernah digunakan sebagai sarana aktivitas, sama dengan artefak yang ditemukan di Desa Setrojenar. Artefak lain dan nonartefak tidak ditemukan. Kenyataan itu memberi gambaran bahwa Desa Wingko memiliki arena aktivitas ritual. Jenis ritualnya tidak diketahui, karena bukti-bukti yang memperkuat dugaan itu tidak ditemukan atau belum ditemukan sampai saat ini Desa-desa kuna lain yang terletak di sebelah timurnya berada di pantai selatan Yogyakarta hingga pantai selatan Jawa Timur.

\section{Desa Krakal}

Krakal merupakan sebuah pantai indah terletak sekitar $180 \mathrm{~km}$ di sebelah timur Desa Wingko. Desa kuna yang terletak antara Wingko dan Krakal adalah Gunungwingko. Desa Krakal terletak sekitar 50 meter di sebelah utara pantai Samudera Hindia. Desa ini terletak pada suatu beting gisik yang berukuran panjang 300 meter dengan lebar 100 meter. Di sebelah barat situs terdapat sebatang sungai kecil yang di musim kemarau tidak berair. Pada penelitian tahun 1980 sungai ini masih berair, meskipun debitnya kecil di musim kemarau. Di sebelah selatan beting gisik yang memanjang timur-barat terdapat tebing agak curam dan di sebelah selatan tebing terdapat gisik.

Artefak yang ditemukan berupa pecahan tembikar, alat batu, dan batu penggosok, sedangkan nonartefak berupa tulang manusia, tulang hewan, dan cangkang kerang. Pecahan tembikar berasal dari berbagai jenis bentuk, baik yang diberi pola hias maupun pecahan tembikar tanpa pola hias. Salah seorang penduduk yang mempunyai ladang di dekat beting gisik menginformasikan bahwa pecahan-pecahan tembikar itu meupakan sisa-sisa pembuatan garam yang pernah berlangsung di lokasi tersebut. Alat batu berupa beliung persegi yang sudah diupam dan dari bekas-bekasnya, beliung tersebut pernah digunakan sebagai alat untuk menggosok. Batu penggosok lain dibuat dari batu kali dari jenis andesit dan jenis barang yang digosok dengan batu itu. belum diketahui. Tulang manusia ditemukan di bagian barat beting gisik dalam jumlah cukup terbatas, tulang hewan berasal dari hewan bertulang belakang, dan cangkang kerang.

Bukti-bukti berupa sisa makanan dan sisa aktivitas tersebut, menggambarkan adanya suatu desa yang pernah ada di pantai selatan Gunung Kidul. Aktivitas yang dilakukan belum diketahui dengan pasti, tetapi apabila informasi tentang pembuatan garam sudah berlangsung sejak lama, maka dapat diduga bahwa pembuatan garam merupakan matapencaharian yang pernah ditekuni. Apabila dugaan itu benar, maka para pembuat garam bertempat tinggal sementara di desa tersebut, terutama pada musim kemarau. Pada musim hujan mereka kembali ke desa yang terletak di sebelah utaranya. Mereka memilih wilayah itu untuk mengeksploitasi sumberdaya akuatik berupa air laut, karena lahan di sebelah utaranya merupakan lahan gersang, lebih-lebih pada musim kemarau. 


\section{Desa Panggul}

Desa kuna ini terletak di dekat Teluk Panggul, sekitar 250 meter hingga 500 meter di sebelah utara pantai Samudera Hindia. Desa yang berlokasi di atas bukit pasir itu, berdasarkan penelitian yang dilakukan panjangnya antara 1400 meter hingga 2500 meter, sedangkan lebarnya antara 75 meter hingga 100 meter. Di sebelah timur desa terletak Kali Konang dan di sebelah baratnya terdapat Kali Gedangan. Lembah yang terletak di antara dua batang sungai itu merupakan lahan subur. Artefak yang ditemukan sebagian besar pecahan tembikar yang paling banyak berbentuk periuk, sedangkan mangkok jumlahnya sangat kecil. Sebagian besar pecahan tembikar berpola hias, sedangkan lainnya tidak berpola hias. Temuan nonartefak jumlahnya tidak banyak berasal dari pecahan tulang vertebrata. Sisa-sisa makanan dan artefak itu tidak cukup untuk membuktikan bahwa situs tersebut bukan situs permukiman, melainkan digunakan untuk keperluan lain misalnya religi. Permukiman menetap diduga terletak di desa-desa yang sekarang terletak di sebelah utaranya.

\section{Desa Meleman}

Desa Meleman kuna berada pada bukit pasir tua dan bukit pasir muda, terletak 500 meter hingga 3000 meter di sebelah utara pantai Samudera Hindia dan keduanya bermuara di Samudera Hindia. Kali Bondoyudo, merupakan kali yang terbesar di dekatnya, terletak di sebelah timur, sedangkan di sebelah barat pada jarak yang lebih jauh terdapat Kali Pancer. Selain dua batang sungai, di situs ini terdapat dua buah rawa, yaitu Rawa Asin dan Rawa Tunjungputih. Rawa Asin memotong bukit pasir muda, terletak agak ke selatan, sedangkan Rawa Tunjungputih terletak di bagian barat laut. Kondisi Rawa Asin sekarang, berubah fungsi sebagai lahan persawahan subur. Secara umum, lahan di antara dua lembah sungai tersebut cukup subur dan dijadikan lahan pertanian.

Artefak yang ditemukan di situs ini terdiri atas beberapa jenis antara lain pecahan tembikar, pemberat jala, manik-manik, dan alat besi. Pecahan tembikar menggambarkan berasal dari beberapa bentuk periuk dan mangkok, dengan beberapa motif hias dan polos. Alat besi yang ditemukan berasal dari senjata tusuk dan senjata potong dalam jumlah cukup banyak. Nonartefak berupa pecahan tulang hewan antara lain ikan dan hewan vertebrata besar seperti kambing dan sapi. Selain itu, batu apung yang ditemukan di situs tersebut dalam jumlah cukup banyak. Nonartefak yang cukup penting berupa pecahan tulang manusia dalam keadaan hancur akibat penggalian liar yang dilakukan oleh pemburu harta karun.

Kesuburan tanah, jumlah temuan melimpah, dan ukuran situs yang cukup luas, menggambarkan bahwa Situs Meleman merupakan bekas desa kuna yang cukup besar di jamannya. Meleman merupakan desa yang relatif baru, sedangkan desa-desa yang lebih tua terletak di sebelah utaranya, yaitu Wotgalih dan Tunjungrejo. Di Desa Tunjungrejo pernah ditemukan rangka manusia lengkap dengan bekal kubur, 
tembikar, senjata yang dibuat dari besi, dan benda-benda yang dibuat dari emas. Kedua desa tersebut mungkin berumur lebih tua dan ketika pembentukan lahan di sebelah selatannya selesai, maka banyak pendatang yang menghuni lahan baru tersebut yang kemudian menjadi Desa Meleman sekarang.

Desa kuna Meleman mungkin dapat dihubungkan dengan peristiwa sejarah, terutama sejarah Kerajaan Majapahit, karena salah satu nama tempat yang terdapat di wilayah itu disebut-sebut dalam kitab Negarakretagama pada waktu perjalanan Hayam Wuruk, seperti yang disadur oleh Slametmulyana (1979:285). Dalam Pupuh XXII/1 disebutkan ...

“... Di Dampar dan Patunjungan Sri Baginda bercengkerma menyisir tepi lautan ke jurusan timur turut pesisir datar, lembut-limbur dilintas kereta. Berhenti beliau di tepi danau penuh teratai, tunjung sedang berbunga ..."

Dampar merupakan sebuah desa yang terletak di sebelah timur Patunjungan. Sementara itu, Patunjungan mungkin merupakan nama desa kuna dari yang sekarang bernamaTunjungrejo. Selanjutnya, dalam Pupuh XXII/2 disebutkan

"...Terlangkahi keindahan air telaga yang melambai-lambai dengan lautan. Danau ditinggalkan, menuju Wedi dan Guntur tersembunyi di tepi jalan. Kasogatan Bajraka termasuk wilayah Taladwaja sejak dulu kala. Seperti juga Patunjungan, akibat perang, belum kembali ke asrama...."

Kata-kata akibat perang menggambarkan temuan senjata tusuk dan senjata potong yang banyak banyak ditemukan di sirus tersebut, sehingga situs ini dapat dihubungkan dengan peristiwa sejarah Majapahit tersebut, yaitu sekitar abad ke-14 M.

\section{Desa Karangmenjangan}

Karangmenjangan merupakan salah satu desa yang terletak di pantai selatan wilayah kecamatan Tempursari. Deposisi lahan berjalan agak lambat, sehingga Karangmenjangan menduduki bukit pasir tua yang di sebelah selatannya masih berupa rawa. Rawa itu sekarang dimanfaatkan sebagai lahan pertanian. Selain di bagian selatan, di sebelah timur desa itu dibatasi oleh lahan sawah yang mendapat pasokan air dari Kali Rawan yang mengelilingi situs di barat kemudian melingkar ke selatan dan kemudian mengalir ke timur yang akhirnya bermuara di Samudera Hindia. Bekas desa kuna itu panjangnya 1000 meter dan lebar 400 meter. Desa yang luasnya sekitar 40 hektar itu di sebelah timurnya terdapat deretan beting gisik yang lebih muda.

Artefak yang ditemukan adalah pecahan tembikar, baik polos maupun bermotif hias dan alat-alat dari besi. Pecahan tembikar mengacu pada bentuk mula periuk, mangkok, tutup, sedangkan motif hias berasal dari teknis gores dan tera. Teknik gores menghasilkan motif segittiga dan bentuk geometrik lainnya, sedangkan teknik tera 
menghasil motif yang terdiri atas segitiga, segi empat, dan motif duri ikan seperti yang ditemukan di situs-situs pantai selatan lainnya. Nonartefak berupa batu apung, cangkang kerang, dan gigi manusia. Batu apung terdapat bekas-bekas pakai, yaitu keausan pada beberapa sisinya, gigi manusia dan cangkang kerang jumlahnya tidak banyak. Penduduk menginformasikan bahwa penggali liar pernah menemukan rangka manusia dan manik-manik. Informasi selanjutnya menyebutkan adanya temuan berupa gandik, pipisan, pecahan alat besi, barang-barang dari emas, arca ganesa, dan manikmanik.

Keletakan desa ini sangat terpencil ke dua arah, utara dan selatan. Aksesibiltas ke utara tertutup oleh dataran tinggi sedangkan ke selatan terhalang oleh Samudera Hindia. Migrasi penduduk ke daerah ini tidak melewati jalur utara dan selatan, melainkan melalui jalur laut dari arah timur atau barat. Para pendatang berasal dari daerah-daerah yang terletak di sebelah timur dan barat, seperti Jember dan Malang. Ketika jalur transportasi telah memadai, maka banyak orang-orang dari utara pindah ke daerah ini untuk mengeksploitasi sumberdaya alam.

\section{Desa Jatiagung}

Bekas desa kuna ini memanjang sekitar 1200 meter timur-barat dan melebar ke selatan sekitar 1300 meter. Wilayah yang diteliti sekitar 156 hektar itu, belum meliputi seluruh lahan bekas desa kuna itu, dan mungkin desa itu masih lebih luas. Kondisi Desa Jatiagung sekarang dipadati oleh perumahan penduduk dan keletakannya jauh dari pantai, yaitu sekitar sembilan kilometer di sebelah utara garis pantai Samudera Hindia. Keadaan air tanah cukup melimpah, karena permukaan air sumur kedalamannya sekitar 300 centimeter yang terdapat di beberapa tempat. Sumber air lain yang terdapat di sekitar Jatiagung berupa air permukaan, yaitu Rawa Plumpung, Rawa Bujel, Rawa Munengan, dan Rawa Jadungan Air permukaan lainnya berupa dua batang sungai,yaitu Kali Bondoyudo terletak di sebelah timur dan Kali Malang terletak di sebelah barat. Kedua sungai dan rawa merupakan ciri bahwa lahan yang terbentuk merupakan dataran aluvial pantai dan hasil bentukan oleh angin. Dengan demikian, desa kuna Jatiagung pada awalnya menempati bukit pasir tua dan karena pertambahan daratan ke arah laut berlangsung lama, maka desa tersebut letaknya lebih jauh dari pantai.

Artefak dan nonartefak yang ditemukan sebagai bukti kehidupan mereka masa lampau cukup banyak dan bervariasi jenisnya. Artefak antara lain terdiri atas pecahan tembikar, manik-manik, dan alat batu, sedangkan nonartefak terdiri atas tulang manusia, tulang hewan termasuk karapas (carapax) kura-kura, dan batu apung yang beberapa di antaranya telah aus sebagai akibat pemakaian. Pecahan tembikar berasal dari beberapa bentuk dan yang menonjol adalah periuk dan mangkok. Salah satu motif hias tera memiliki persamaan dengan Jatiagung, Meleman, dan situs-situs di pantai selatan Jawa Tengah dan Yogyakarta, terutama tera motif duri ikan dan variasi- 
variasinya. Artefak dan nonartefak itu menggambarkan aktivitas penduduk desa kuna dan sedikit memberi gambaran tentang matapencaharian mereka masa lampau. Meskipun demikian, gambaran masyarakat masa lampau di desa kuna tersebut belum dapat digambarkan seluruhnya.

\section{Desa Panggulmlati}

Desa kuna ini letaknya sekitar tiga setengah kilometer di sebelah baratdaya Jatiagung dan sekitar 1500 meter di sebelah utara pantai Samudera Hindia. Di sebelah barat mengalir Kali Bondoyudo dan di sebelah timur terdapat sebuah rawa yang dinamakan Rawa Singa. Daerah yang diteliti belum mencerminkan luas desa tersebut, karena tidak menjangkau daerah luas. Akan tetapi, dari bekas-bekas penggalian liar, luas desa kuna tersebut sekitar dua setengah hektar. Artefak dan nonartefak yang ditemukan hampir sama dengan Desa Jatiagung, hanya Jatiagung lebih beravariasi jenisnya. Dari ciri-ciri itu, Panggulmlati merupakan desa kuna yang lebih kecil daripada Desa Jatuagung.

\section{unungwingko Desa Tertua}

Artefak yang dibuat dari tanah liat bakar pada umumnya berbentuk cukup unik. Wadah yang dibuat dari tanah liat bakar yang termasuk unik adalah mangkok berbentuk nyiru yang diameternya hampir sama dengan nyiru, bagian dasarnya terdapat motif hias anyaman dan tingginya sekitar tujuh centimeter dan tidak pernah ditemukan bentuk utuhnya. Bentuk unik lainnya adalah mangkok berdasar runcing yang terdapat lubang pada bagian runcing itu. Tanah liat bakar berbentuk nonwadah berupa manik-manik, batangan terakota (berbentuk empat persegi panjang), dan bentuk-bentuk lain yang sukar dicari padanan bentuknya yang berdasarkan bentuk itu diduga sebagai alat upacara. Rangka manusia dikuburkan dalam beberapa posisi, yaitu sekunder dan primer. Semua temuan itu terdapat di BPT, sedangkan BPM mengandung temuan yang memiliki bentuk sama dan berbeda dan tidak terdapat rangka manusia. Pecahan tembikar di BPM memiliki persamaan, khususnya pola hias anyaman, tetapi pecahan gerabah berteknik hias tera yang persamaannya banyak ditemukan di situs-situs lain, khususnya di lapisan budaya atas. Di luar penelitian, penduduk menemukan barang-barang yang dibuat dari perunggu seperti genta, talam, dan keramik berbentuk teko. Setelah diselaraskan dengan lapisan budaya, genta perunggu dan talam terletak di lapisan budaya ketiga, sedangkan teko keramik terletak di lapisan budaya keempat.

Data etnografi yang diinformasikan penduduk berupa matapencaharian membuat garam. Proses pembuatannya dengan menebarkan air laut ke permukaan pasir, kemudian setelah kering dimasukkan dalam suatu wadah anyaman dan disiram dengan air laut. Air laut yang dituangkan ke pasir kering yang mengandung garam (bleng) itu kemudian direbus hingga kental. Setelah dingin, air yang kental itu 
berubah menjadi garam. Proses merebus bleng berlangsung pada malam hari dan pagi harinya banyak pedagang datang untuk membeli garam. Oleh para pedagang garam itu dijual ke Yogyakarta dan daerah di sekitarnya. Para pembuat garam itu hidup berkelompok di atas bukit pasir dan lokasinya agak jauh dari muara sungai, agar kualitas garam yang dihasilkan bermutu bagus.

Proses pembentukan bentang lahan tidak dapat dilepaskan dari aktivitas gunungapi yang pasirnya dibawa oleh Kali Opak dan Kali Progo kemudian terendapkan di pantai, dan selanjutnya terbentuk lahan tersebut. Sebelum BPT terbentuk di selatannya masih berupa lautan luas dan setelah itu laut terbendung dan garis pantai bergeser ke selatan. Demikian seterusnya, sehingga terbentuk BPR. Pembentukan lahan tersebut berlangsung horisontal dan serta merta terbentuk pula beberapa lapisan secara vertikal. Apabila setiap lapisan tanah dihuni oleh manusia yang kemudian ditinggalkan oleh suatu sebab, maka lapisan-lapisan itu berubah menjadi lapisan budaya. Berdasarkan pembentukan lahan secara vertikal itu di Gunungwingko terjadi empat lapisan budaya, lapisan budaya pertama terletak di bawah dan lapisan budaya yang lebih muda masing-masing terletak di atasnya.

Dalam menentukan pertanggalan lapisan budaya tersebut digunakan beberapa cara, yaitu pertanggalan absolut dan relatif yang sampelnya diambil dari tiap lapisan budaya tersebut. Pertanggalan absolut digunakan tulang dan arang sebagai media analisis, sedangkan pertanggalan relatif dihubungkan dengan katastropik dan pecahan keramik yang terdapat di suatu lapisan tanah. Berdasarkan cara itu, lapisan budaya pertama di BPT berasal dari 2000 tahun lampau hingga abad ke-6 M, lapisan budaya kedua berasal dari abad ke-6 hingga abad ke-10, lapisan budaya ketiga abad ke-10 hingga abad ke 14, sedangkan lapisan budaya keempat berasal dari abad ke-14 hingga abad ke-17 M (Goenadi, 2001: 222-41). Empat lapisan budaya itu menggambarkan bahwa Gunungwingko masa lampau pernah dihuni selama empat fase kehidupan dan bahkan berlangsung terus hingga permukiman sekarang.

Permukiman manusia masa lampau meninggalkan sisa-sisa kehidupan yang terdapat pada suatu situs. Keberadaan suatu situs tidak dapat dipisahkan dari lingkungan alam di sekitarnya, karena lingkungan alam, manusia, dan budaya merupakan tiga faktor yang saling berhubungan dan saling mempengaruhi (Soejono, 1986: 31). Sisa-sisa kehidupan yang terdapat pada suatu situs dapat digunakan sebagai media untuk melukiskan kembali matapencaharian, aktivitas religi, dan aktivitas-aktivitas lain yang pernah dilakukan di suatu situs. Sejalan dengan pernyataan itu, maka matapencaharian masyarakat Gunungwingko masa lampau dapat dilukiskan kembali melalui beberapa aspek, yaitu lingkungan alam, artefak, dan nonartefak serta ditunjang oleh data etnografi. 
Data penunjang matapencaharian masyarakat Gunungwingko masa lampau terdiri atas tembikar berbentuk wadah dan nonwadah. Tembikar berbentuk nyiru diduga sebagai salah satu alat yang digunakan untuk membuat garam hingga abad ke-18. Informasi itu berasal dari Van de Velde (1988: 79) sebagai hasil wawancara dengan penduduk setempat. Bentuk mangkok berdasar runcing yang ditemukan di Gunungwingko memiliki persamaan dengan temuan sejenis dari luar situs tersebut. Situs pembuatan garam di Pulau Kiheijima, Jepang, terletak di tepi pantai menggunakan mangkok berdasar runcing sebagai salah satu wadah dalam pembuatan garam dengan cara merebus air laut (Kondo, 1975: 61-5). Berdasarkan persamaan itu, mangkok berdasar runcing yang ditemukan di Gunungwingko, fungsinya dapat disejajarkan, yaitu sebagai salah satu alat dalam pembuatan garam. Terakota batangan fungsinya tidak diketahui dengan jelas, karena tidak ditemukan persamaannya dengan data etnografi di Gunungwingko. Akan tetapi, fungsinya dapat dibandingkan dengan bentuk artefak yang sama dari situs pembuatan garam di Cheshire, Inggris. Alat tersebut berfungsi sebagai pembatas panggangan (grade) suatu wadah yang digunakan untuk merebus air laut dalam proses pembuatan garam (Bestwick, 1975: 68). Berdasarkan persamaan bentuk dan fungsi artefak itu, dapat diketahui bahwa terakota batangan yang ditemukan di Gunungwingko diduga sebagai alas wadah dalam merebus bleng.

Berdasarkan uraian itu, Gunungwingko merupakan sebuah desa kuna yang penduduknya bermatapencaharian membuat garam sebagai matapencaharian pokok. Beberapa alat yang diduga sebagai alat dalam pembuatan garam tersebut terdapat di BPT dan BPM yang menggambarkan bahwa pembuatan garam dilakukan secara turun temurun bahkan berlangsung hingga masa penjajahan Jepang. Selain itu, tampak adanya usaha untuk mendekati air laut sebagai sumber bahan utama. Setelah BPT terbentuk beberapa lama, kemudian terbentuk BPM mereka pindah untuk mendekati air laut yang tercermin dari temuan artefak sama di BPT dan BPM. Matapencaharian sampingan dapat diperoleh gambarannya dari pemberat jala dan tulang binatang seperti ikan dan binatang bertulang belakang lainnya, misalnya rusa, kelinci, dan penyu. Berdasarkan data itu gambaran aktivitas yang berkaitan dengan matapencaharian adalah menangkap ikan dan berburu binatang. Penangkapan ikan dilakukan di sungai-sungai, laut, dan rawa, sedangkan perburuan binatang dilakukan di semak-semak yang tumbuh di lingkungan pantai.

Aktivitas ritual dapat digambarkan dari temuan rangka manusia yang ditemukan di beberapa lapisan budaya. Di dalam lapisan budaya pertama terdapat tiga struktur kubur yang salah satunya dikubur dengan sistem penguburan primer dan dilengkapi dengan bekal kubur antara lain tembikar. Dalam lapisan budaya kedua ditemukan struktur kubur dengan sistem penguburan sekunder yang dilengkapi dengan beberapa bekal kubur, selain tembikar ditemukan pula manik-manik. Lapisan budaya ketiga mengandung struktur kubur dengan sistem penguburan sekunder, kepala terletak di 
timur, dengan bekal kubur berupa kendi dan periuk berukuran kecil. Struktur kubur yang terdapat di lapisan budaya keempat tidak lengkap sehingga tidak diketahui sistem penguburannya. Sistem penguburan yang meliputi orientasi penguburan, dan bekal kubur yang disertakan menggambarkan adanya suatu kepercayaan yang dianut pada waktu itu.

Gambaran tentang keberadaan pecahan tembikar bermotif duri ikan dari teknik tera tatap di Gunungwingko yang ditemukan di lapisan budaya ketiga, di desa-desa kuna di pantai selatan tidak dapat diketahui konteks lapisan tanahnya, sehingga tidak dapat ditentukan pertanggalannya. Berdasarkan persamaan motif hias tembikar tersebut dapat diduga bahwa desa-desa kuna di pantai selatan Jawa lain sejaman dengan fase kehidupan ketiga di Desa Gunungwingko. Dengan adanya persamaan itu, maka Desa Gunungwingko masa lampau telah berlangsung selama lebih kurang 1400 tahun, desadesa lain di pantai selatan Jawa baru muncul. Masalah mengenai asal perkembangan desa belum diketahui, apakah berasal dari Gunungwingko kemudian menyebar ke arah timur dan barat, atau desa-desa itu baru muncul kemudian tanpa adanya pengaruh tersebut.

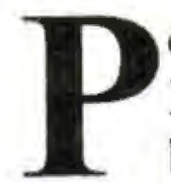

\section{emberdayaan}

Desa kuna Gunungwingko merupakan salah satu desa paling tua dan paling besar di antara desa-desa kuna di pantai selatan Jawa. Fase kehidupan yang terjadi di desa tersebut berlangsung sejak masa akhir prasejarah hingga masa sejarah. Pengaruh budaya sejarah paling menonjol yang masuk ke Gunungwingko adalah genta perunggu yang biasa digunakan dalam upacara ritual Agama Hindhu, terutama pada fase kehidupan ketiga. Pada masa itu, di wilayah sebelah utara Gunungwingko merupakan wilayah kerajaan besar seperti Kerajaan Mataram Kuna dan berlangsung terus hingga kerajaan itu berpindah ke Jawa Timur. Keberadaan kerajaan-kerajaan tersebut menyebabkan Gunungwingko mendapat pengaruh budaya, meskipun merupakan daerah pinggiran, sehingga Gunungwingko berkembang menjadi desa yang lebih besar.

Matapencaharian penduduk Desa Gunungwingko masa lampau tidak mendapat pengaruh dari pusat pemerintahan, karena matapencaharian berkaitan erat dengan lingkungan di sekitranya. Meskipun demikian, produksi garam merupakan salah satu produksi penting dalam kehidupan manusia pada masa itu hingga sekarang, karena garam merupakan salah satu keperluan pokok sehari-hari bagi manusia. Proses pembuatan yang dilakukan berbeda dengan daerah pembuatan garam lainnya di Jawa, sehingga memiliki keunikan sendiri, lebih-lebih merupakan pembuatan garam paling tua yang dapat diketahui sampai saat ini. Berdasarkan nilai sejarah yang cukup penting itu, maka cara-cara pembuatan garam tradisional yang telah punah itu dapat dihidupkan kembali, agar dapat dilestarikan. 
Pelestarian budaya tradisional itu merupakan teks dalam lembaran sejarah masa lampau yang dapat dibaca kembali oleh generasi yang hidup sekarang, lebih-lebih oleh generasi muda. Hal itu dapat menimbulkan kebanggaan daerah dan pada akhirnya diharapkan dapat menimbulkan rasa cinta kepada tanah air. Pembuatan garam yang dihidupkan kembali itu dapat pula dikemas menjadi objek wisata untuk melengkapi wisata alam yang sudah berkembang di daerah itu. Demikian pula pemberdayaan situs, dapat dilakukan untuk menambah objek wisata tersebut. Caranya ialah dengan membuat museum terbuka dari hasil penelitian di situs tersebut, untuk membuka kembali teks sejarah kehidupan masa lampau yang masih tertimbun tanah selama beberapa ribu tahun. Keuntungan lain dari pemberdayaan hasil penelitian ini adalah menambah penghasilan masyarakat, pemerintah daerah, dan menambah identitas daerah setempat.

\section{KEPUSTAKAAN}

Bestwick, J.D. 1975. Romano-British Inland Salting at Middlewich (Salinae), Cheshire. Dalam K.W. de Brisay dan K.A. Evans (eds.). Salt the Study of Ancient Industry Report on Salt Weekend. Held at the University of Essex, Colchester.

Dibyosaputro, Suprapto. 1997. Geomorfologi Dasar. Fakultas Pascasarjana. Universitas Gadjah Mada, Yogyakarta.

Goenadi Nitihaminoto. 2001. Situs Gunungwingko: Sebuah Rekonstruksi Kehidupan Masyarakat Akhir Masa Perundagian. Disertasi. Universitas Gadjahmada Yogyakarta.

Kondo, Yoshiro. 1975. The Salt Industry in Ancient Japan. Dalam K.W. de Brisay dan K.A. Evans (eds.) Salt the Study of Ancient Industry Report on Salt Weekend. Held at the University of Essex, Colchester.

Mundardjito. 1993. Pertimbangan Ekologi dalam Penempatan Situs Masa Hindu-Buda di Daerah Istimewa Yogyakarta: Kajian Arkeologi Ruang Skala Makro. Disertasi. Program Pascasarjana, Universitas Indonesia, Jakarta. 
Pannekoek, A.J.1949. Outline of Geomorphology of Java. Tijdschrift Nederlands Aarderijkskundig Genootschap 66. The Hague, Martinus Nijhoff.

Reineck, H.E. dan I.B. Singh. 1975. Depositional Sedimentary Environments. Springer Verlag, Berlin Heidelberg, New York.

Slametmulyana. 1979. Nagarakretagama dan Tafsir Sejarahnya. Bhratara Karya Aksara, Jakarta.

Soejono, R.P. 1986. Lokal Genius dalam Sistem Teknologi Prasejarah. Kepribadian Budaya Bangsa (Local Genius). Dunia Pustaka Jaya, Jakarta.

Sutikno. 1989. The Indonesian Journal of Geography 19 (58). Faculty of Geography, Gadja Mada University, Yogyakarta.

Van der Hoop, A.N.J. TH. A. Th. 1938. De Prehistorie. Geschiedenis van Nederlandsch Indie. Deel I, Amsterdam.

Bandung.

Van de Velde, Peter. 1988. On an Early Salt Industry on Java's South Coast. Verhandelingen van het Koninklijk instituut voor $T^{\wedge} a$ al, - Land-, en Volkenkunde 131. Foris Publications, Dordecht-Holland. 